\title{
Experimental study on comparison of the plasticizer effect on PVA fiber reinforcement concrete
}

\author{
K. Hemalatha ${ }^{1}$, Mallikarjuna Reddy $\mathrm{V}^{2}$, Guntupally Nikhil ${ }^{3}$ \\ ${ }^{1}$ Assistant Professor, Department of Civil Engineering, Gokaraju Rangaraju Institute of Engineering and Technology, Hyderabad, \\ Telangana, 500090, India \\ ${ }^{2}$ Professor \&Head, Department of Civil Engineering, Gokaraju Rangaraju Institute of Engineering and Technology, Hyderabad, \\ Telangana, 500090, India \\ ${ }^{3}$ Post graduate student, Department of Civil Engineering, Gokaraju Rangaraju Institute of Engineering and Technology, Hyderabad, \\ Telangana, 500090, India
}

\begin{abstract}
A high-strength Concrete structure is what everyone tries to achieve through the project. So many studies are being studied with various types of fibers. In this paper, I have used PVA fibers with two different types of plasticizers. The main purpose of this study is to find the amount of plasticizer to be used and which is feasible to be used for different proportions of PVA fibers. We have casted $0.125 \%, 0.250 \%$, $0.375 \%$, and $0.50 \%$ of PVA fiber in the proportion of the weight of cement. We have also studied their compressive strength and split tensile strength. By which we have decided the optimum dosage of plasticizes to be used for the different proportions of PVA fiber.
\end{abstract}

\section{INTRODUCTION}

In reinforced concrete beams majorly consists of concrete in their structure. Concrete is a composite material that is composed of fine aggregate, coarse aggregate, cement, and water. All these materials play a very important role in the strengthening of concrete. As reinforced concrete is a composite material as concrete structures have low tensile strength, ductility so to reduce these effects steel is induced in the concrete. In general, beams fail specifically in Flexural failure and shear failure. Flexural failure approach bending failure. Shear failure is the sliding failure alongside the plan that is parallel to the force applied. To reduce the shear effect in structure stirrups are provided. In reinforced concrete, the compressive strength of concrete and tensile strength of steel work together so that the member can sustain the wind, earthquakes, vibrations, and other forces over a considerable span. In 19th century a revolution has occurred in the construction industry due to the invention of reinforced concrete and concrete became one of the world's most common building materials. For the design of reinforced concrete beams, mechanical properties are to be considered like strength, durability, ductility, toughness, weldability, etc. these mechanical properties can be affected by many factors some of them are chemical composition, heat treatment, manufacturing process. In construction, steel has various advantages which are it has high durability. As steel can withstand external pressures such as earthquakes whereas concrete alone cannot withstand the force. The rebar is usually grooved with ribs, lugs, to increase the bond with concrete and reduce the risk of slippage.

In the construction of a structure, there are many components like columns, slabs, beams, walls, foundation, frames. They are all made of reinforced concrete and can be divided into precast or cast in site concrete. For effectively constructing a building is by using proper implementing and designing. Even if there is a small change in implementation than from the design there will be huge changes in material cost, construction schedule, operating cost, ultimate strength. Three physical characteristics give reinforced concrete its special properties like the coefficient of thermal expansion of concrete and steel is almost the same, the steel bars are usually grooved with ribs, lugs to increase the bond with concrete and reduce the risk of slippage. Due to the chemical reaction between steel and concrete ph. value decreases from13.5-12.5 to 8.5, the ph. value of water is in equilibrium with calcite (calcium carbonate) and the steel is no longer passivated. As a thumb rule just to provide a thought on a significant degree, steel is protected at ph. $\sim 11$ however begins to corrode below $\mathrm{Ph} \sim 10$ depending on steel characters and nearby physiochemical conditions when cement gets carbonated. Carbonation of cement alongside chloride entrance is

\footnotetext{
* Corresponding author: hema1177@grietcollege.com
} 
among the main purposes for the failure of reinforcement bars in concrete. As it corrodes, steel rebar's swell and build the tensile load on concrete which starts to crack and spall, making an opening that leads to further and quick damage of steel and concrete. This requires costly repair and maintenance and whenever permitted to advance far enough it can reduce the strength of the structure. However, the issue of corrosion-related with steel rebar diminishes its lifetime and there are many ways by which we can reduce the corrosion by coating the steel with anticorrosive material but these are very costly. In recent advancements, steel rebar's are replaced by fiberreinforced rebar's.

\subsection{Fiber Reinforced concrete}

There are many studies have conducted on fiber reinforced concrete in this we mix different types of fibers in the conventional concrete to reduce the crack formation. There are many types of fibers like Steel, PVA, Polypropylene, bamboo, etc. By using these fibers the structural strength gets increased by these fibers. These fibers are short in length so they get easily distributed throughout the concrete. Due to the various types of fibers in the concrete the characteristics also change. The strength of the concrete can be increased by using these fibers. By using different types of fibers there will be different types of effects in the concrete. They increase the features like the availability of tensile reinforcement in all directions, mix cohesion, permeability over long distances, freeze-thaw resistance, resistance to explosive spalling in case of a severe fire, resistance to plastic shrinkage during curing, structural strength, etc. we can also use two different types of fibers in the concrete there will be different effects in the concrete. In some cases, steel rebar can be replaced by these fibers.

\section{Material}

\subsection{Cement}

We have used OPC 53 locally available grade cement. We have done the test on the cement that is mentioned below in table 1 .

Table 1. Cement Tests.

\begin{tabular}{|c|c|}
\hline Test on Cement & Results \\
\hline Specific Gravity & $3.220 \mathrm{v}$ \\
\hline Normal Consistence & $27 \%$ \\
\hline Initial Setting Time & $42 \mathrm{~min}$ \\
\hline Fineness Test & 7.5 \\
\hline
\end{tabular}

\subsection{Fine Aggregate}

We have used River sand as the fine aggregate which is available locally in the area. Hence we tested the material in the laboratory before using it in the experiment. The test results are mentioned below in table 2 .

Table 2. Fine Aggregate Tests.

\begin{tabular}{|c|c|}
\hline $\begin{array}{c}\text { Test on } \\
\text { Cement }\end{array}$ & Results \\
\hline $\begin{array}{c}\text { Specific } \\
\text { Gravity }\end{array}$ & 2.7 \\
\hline $\begin{array}{c}\text { Water } \\
\text { Absorption }\end{array}$ & $1 \%$ \\
\hline $\begin{array}{c}\text { Fineness } \\
\text { Modulus }\end{array}$ & 2.76 \\
\hline
\end{tabular}

\subsection{Coarse Aggregate}

We have used crushed stone of two different sizes of $10 \mathrm{~mm}$ and $20 \mathrm{~mm}$ in equal proportions. So that the mix could be uniform.

Table 3. Fine Aggregate Tests

\begin{tabular}{|c|c|}
\hline $\begin{array}{c}\text { Test on } \\
\text { Cement }\end{array}$ & Results \\
\hline $\begin{array}{c}\text { Specific } \\
\text { Gravity }\end{array}$ & 2.67 \\
\hline $\begin{array}{c}\text { Water } \\
\text { Absorption }\end{array}$ & $0.89 \%$ \\
\hline $\begin{array}{c}\text { Aggregate } \\
\text { Impact } \\
\text { Value }\end{array}$ & 7.3 \\
\hline
\end{tabular}

\subsection{PVA Fibers}

Polyvinyl alcohol fibers (as shown in Figure 1) are very evenly manufactured in size and shape so they spread throughout the concrete which gives a good performance in reinforcement. They are suitable for a wide range of applications in concrete. So, it also has a good crackfighting ability, bond strength at the molecular level, etc. the fibers have a good bond at the molecular level with concrete that is much greater than other fibers. Due to the fine nature and size, they disperse uniformly throughout the concrete so the finish will be smooth without any disturbances 
Table 4. Properties of PVA

\begin{tabular}{|c|c|c|}
\hline S No & Specification & Result \\
\hline 1 & Fiber Type & BUNCHY MONOFILAMENTS \\
\hline 2 & Density & 1.29 \\
\hline 3 & Formula & CH2-CH-OH \\
\hline 4 & Length & $12 \mathrm{~mm}$ \\
\hline
\end{tabular}

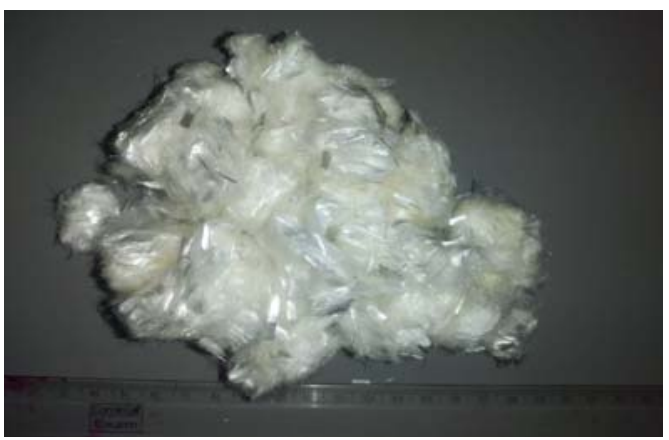

Fig. 1. PVA Fibers

\subsection{Plasticizer}

It is used to make the concrete softer and more flexible and easier to work with. There are many different types of plasticizers available mostly water-reducing admixtures are used. I have used two different types of plasticizers in this project.

\subsubsection{Polycarboxylic ether-based plasticizers (PCE).}

We have used BASF Company plasticizer in this project which is mainly used as the water reducing agent. It helps to high workability and high early strength.

Table 5. Properties of PCE plasticizers

\begin{tabular}{|l|l|}
\hline Aspect & Reddish-brown liquid \\
\hline Relative Density & $1.08 \pm 0.02$ at $25^{\circ} \mathrm{C}$ \\
\hline pH & Greater than or equal to 6 \\
\hline Chloride ion content & Less than $0.2 \%$ \\
\hline
\end{tabular}

\subsubsection{Conplast SP430}

We have used Fosroc company plasticizer in this project which is mainly used to reduce the water and increase the durability and ultimate strength.

Table 6. Properties of Conplast SP 430

\begin{tabular}{|l|l|}
\hline Aspect & Brown liquid \\
\hline Specific gravity & $: 1.18 @ 25^{\circ} \mathrm{C}$ \\
\hline Chloride content & $\begin{array}{l}\text { Nil to BS 5075 / BS: } \\
\text { EN934 }\end{array}$ \\
\hline Aisr entrainment & $\begin{array}{l}\text { Less than } \% \text { additional } \\
\text { air is entrained at normal } \\
\text { dosages. }\end{array}$ \\
\hline
\end{tabular}

\section{Mixing Procedure}

\subsection{Mix Design}

The process of selecting the material for the concrete mix of M-30 grade concrete and determine the relative amount required for the mix of a one-meter cube.

\section{Mix Proportion:-1:0.25:2.29:4.24:0.43}

Cement: Fly Ash: Fine Aggregate: Coarse Aggregate: Water

The above mix proportions are calculated for M-30 grade concrete for cubes and cylinders.

\subsection{Mixing of Concrete}

The Material has been mixed thoroughly using the Concrete Mixer. I have mixed 3 times thoroughly before mixing water using the machine. We should see that the mix should be of uniform color and there should not be any segregation.

\subsection{Casting of specimen}

Cube Moulds of size $150 \mathrm{~mm}$ X $150 \mathrm{~mm}$ X $150 \mathrm{~mm}$ and Cylinders of size $300 \mathrm{~mm}$ length and $150 \mathrm{~mm}$ diameter are used. The specimens are to be cleaned and dried properly before casting. The quantities of the mix are measured based on their weight. The water is added gradually to maintain the uniform mix.

\subsection{Curing of specimen}

The cubes and cylinders which are casted are demoulded after one day and are placed in a water tank for 28days and are dried before testing the specimen

\section{Experimental Procedure}

First I have conducted the workability test on the mix proportion to fix the amount of plasticizer to be used for a different amount of PVA Fiber used in the concrete mix.

\subsection{Workability}

We have mixed $0.25 \%$ of plasticizer for pure concrete to obtain the consistent mix and a slump value of $70 \mathrm{~mm}$ so it is maintained as the optimum dosage. When the Fibers of different proportions are added to concrete then the plasticizer added also varies. So we have done multiple tests by increasing the amount of plasticizer by $0.1 \%$ until we obtain the slump in the range of $50 \mathrm{~mm}$ to $90 \mathrm{~mm}$. By this process, we have fixed the amount of plasticizers and are mentioned above in the table. 


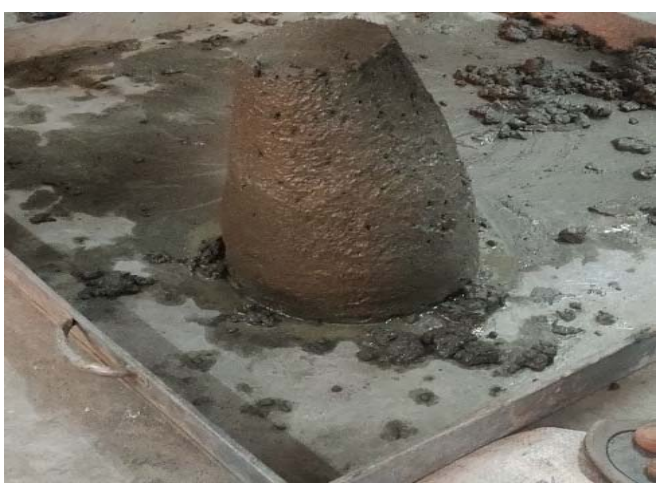

Fig. 2. Workability

Table 7. M-30 Mix proportion of the Specimens

\begin{tabular}{|l|l|l|l|l|l|l|l|}
\hline \multirow{2}{*}{ Sample } & \multicolumn{7}{|c|}{ Percentage \% } \\
\cline { 2 - 8 } & Cement & Fly ash & FA & CA & PVA Fiber & Conplast & PCE \\
\hline 1 & 100 & 25 & 100 & 100 & 0 & 0.25 & 0 \\
\hline 2 & 100 & 25 & 100 & 100 & 0.125 & 0.8 & 0 \\
\hline 3 & 100 & 25 & 100 & 100 & 0.250 & 0.9 & 0 \\
\hline 4 & 100 & 25 & 100 & 100 & 0.375 & 1.0 & 0 \\
\hline 5 & 100 & 25 & 100 & 100 & 0.500 & 1.1 & 0 \\
\hline 6 & 100 & 25 & 100 & 100 & 0 & 0 & 0 \\
\hline 7 & 100 & 25 & 100 & 100 & 0.125 & 0 & 0.25 \\
\hline 8 & 100 & 25 & 100 & 100 & 0.250 & 0 & 1.7 \\
\hline 9 & 100 & 25 & 100 & 100 & 0.375 & 0 & 2.9 \\
\hline 10 & 100 & 25 & 100 & 100 & 0.500 & 0 & 2 \\
\hline
\end{tabular}

In this experiment, I have casted 60 Cubes and 60 cylinders with 10 different types of mix proportions of M30 grade as mentioned in table 7 . In these specimens, I casted half of the specimens with one type of plasticizer and the other half with another. I have performed the compressive test and split tensile test.

\subsection{Compressive Strength Test}

It is a test in which the specimen experience the force from two sides like the specimen is squeezed. Generally, the cubes are placed in between two plates the bottom plate is fixed and the top plate is moveable which exerts pressure on the cube which tends to flatten the specimen.

$$
\text { Compressive Strength }=\frac{\text { Compressive load }(\mathrm{KN})}{\text { Cross Sectional Area of cube }\left(\mathrm{mm}^{2}\right)}
$$

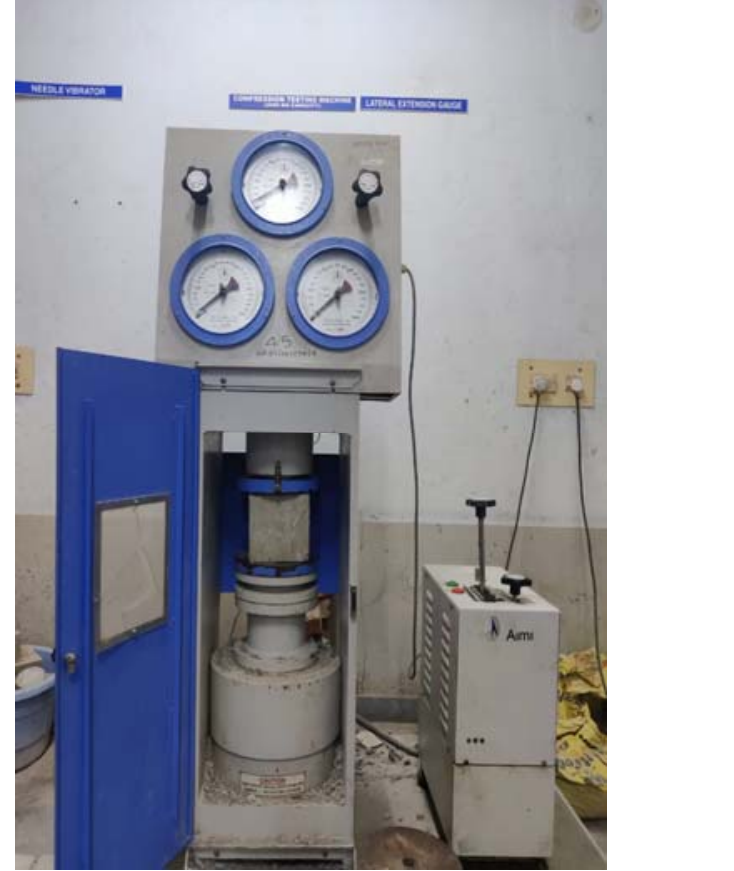

Fig. 3. Compressive Testing Machine

\section{3 .Split Tensile Strength Test}

In this Test we use Cylinders for testing we place them in the longitudinal direction as shown in the figure. The load is applied in a longitudinal direction due to which the as 
that the compressive strength testing machine.

Split Tensile Strength $=\frac{2 \times \text { Load }}{\pi \times \text { Diameter } \times \text { Length }}$

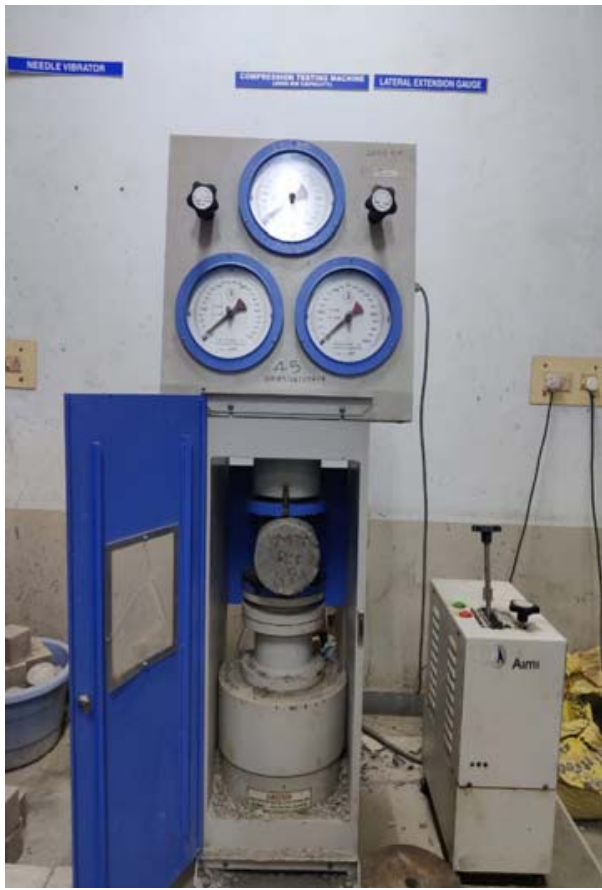

Fig. 4. Compressive Testing Machine

\section{Results and Discussion}

In this project, we have tested the specimen of M-30 grade concrete for 7 days, 14 days and 28 days of curing are tested in laboratory. Results are tabulated and graphs are presented.

\subsection{Results of Compressive strength Test}

\subsubsection{Test results for 7 days.}

The cubes are tested after 7days of curing and are tabulated below in Table 6 and Table 7

Table 8. Test results of cubes using Conplast SP-430 plasticizer

\begin{tabular}{|c|c|c|c|c|c|c|c|}
\hline \multirow{2}{*}{$\underset{\text { le }}{\text { Samp }}$} & \multicolumn{5}{|c|}{ Percentage (\%) } & \multirow{2}{*}{$\begin{array}{c}\text { Fiber } \\
\text { Concre } \\
\text { te }\end{array}$} & \multirow{2}{*}{$\begin{array}{c}\% \% \\
\text { Chan } \\
\text { ge }\end{array}$} \\
\hline & $\begin{array}{l}\text { Cemen } \\
\mathrm{t}\end{array}$ & $\begin{array}{l}\mathrm{Fl} \\
\mathrm{y} \\
\text { as } \\
\mathrm{h}\end{array}$ & FA & $\mathrm{CA}$ & $\begin{array}{l}\text { PVA } \\
\text { Fibe } \\
r\end{array}$ & & \\
\hline 1 & 75 & 25 & 100 & 100 & 0 & 14.16 & \\
\hline 2 & 75 & 25 & 100 & 100 & 0.12 & 14.52 & +2.5 \\
\hline 3 & 75 & 25 & 100 & 100 & 0.25 & 15.76 & +11.3 \\
\hline 4 & 75 & 25 & 100 & 100 & 0.37 & 13.04 & -7.9 \\
\hline 5 & 75 & 25 & 100 & 100 & 0.50 & 11.08 & -21.8 \\
\hline
\end{tabular}

cracks are formed. We use the same testing machi

Table 9. Test results of cubes using Polycarboxylic ether-based plasticizer

\begin{tabular}{|c|c|c|c|c|c|c|c|}
\hline \multirow{2}{*}{$\begin{array}{c}\text { Sampl } \\
\text { e }\end{array}$} & \multicolumn{5}{|c|}{ Percentage (\%) } & \multirow{2}{*}{$\begin{array}{c}\text { Fiber } \\
\text { Concret } \\
\text { e }\end{array}$} & \multirow{2}{*}{$\begin{array}{c}\text { \% } \\
\text { Chang } \\
\text { e }\end{array}$} \\
\hline & $\begin{array}{l}\text { Ceme } \\
\text { nt }\end{array}$ & $\begin{array}{l}\text { Fl } \\
y \\
\text { as } \\
\text { h }\end{array}$ & FA & $\begin{array}{l}\mathrm{C} \\
\mathrm{A}\end{array}$ & $\begin{array}{l}\text { PV } \\
\text { A } \\
\text { Fibe } \\
\text { r }\end{array}$ & & \\
\hline 1 & 75 & 25 & $\begin{array}{l}10 \\
0\end{array}$ & $\begin{array}{l}10 \\
0\end{array}$ & 0 & 14.16 & - \\
\hline 2 & 75 & 25 & $\begin{array}{l}10 \\
0\end{array}$ & $\begin{array}{l}10 \\
0\end{array}$ & 0.12 & 14.48 & +2.3 \\
\hline 3 & 75 & 25 & $\begin{array}{l}10 \\
0 \\
\end{array}$ & $\begin{array}{l}10 \\
0\end{array}$ & 0.25 & 16.48 & +16.38 \\
\hline 4 & 75 & 25 & $\begin{array}{l}10 \\
0 \\
\end{array}$ & $\begin{array}{l}10 \\
0\end{array}$ & 0.37 & 17.36 & +22.59 \\
\hline 5 & 75 & 25 & $\begin{array}{l}10 \\
0\end{array}$ & $\begin{array}{l}10 \\
0\end{array}$ & 0.50 & 17.04 & +20.34 \\
\hline
\end{tabular}

\subsubsection{Comparative Study Of plasticizer}

The comparison of the test results of 7days is represented below in the graph

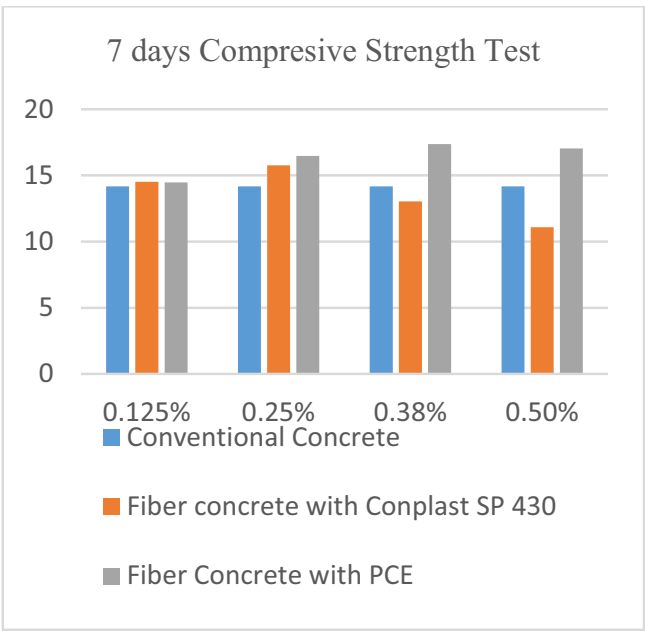

Fig. 5. Comparative Study of 7 days.

\subsubsection{Test results for 28 days.}

The cubes are tested for compressive strength after 28days of curing and are tabulated below in Table 8 and Table 9 .

Table 10. Test results of cubes using Conplast SP-430 plasticizer

\begin{tabular}{|c|c|c|c|c|c|c|c|}
\hline \multirow{2}{*}{$\begin{array}{c}\text { Sampl } \\
\mathbf{e}\end{array}$} & \multicolumn{5}{|c|}{ Percentage (\%) } & \multirow{2}{*}{$\begin{array}{c}\text { Fiber } \\
\text { Concret } \\
\text { e }\end{array}$} & \multirow{2}{*}{$\begin{array}{c}\% \\
\text { Chang } \\
\text { e }\end{array}$} \\
\hline & $\begin{array}{l}\text { Ceme } \\
\text { nt }\end{array}$ & $\begin{array}{l}\mathrm{Fl} \\
\mathrm{y} \\
\text { as } \\
\mathrm{h}\end{array}$ & FA & $\begin{array}{l}\mathrm{C} \\
\mathrm{A}\end{array}$ & $\begin{array}{l}\mathrm{PV} \\
\text { A } \\
\text { Fibe } \\
\mathrm{r} \\
\end{array}$ & & \\
\hline 1 & 75 & 25 & $\begin{array}{l}10 \\
0\end{array}$ & $\begin{array}{l}10 \\
0\end{array}$ & 0 & 35.4 & - \\
\hline 2 & 75 & 25 & $\begin{array}{l}10 \\
0 \\
\end{array}$ & $\begin{array}{l}10 \\
0\end{array}$ & 0.12 & 36.3 & +2.5 \\
\hline 3 & 75 & 25 & $\begin{array}{l}10 \\
0\end{array}$ & $\begin{array}{l}10 \\
0\end{array}$ & 0.25 & 39.4 & +11.3 \\
\hline 4 & 75 & 25 & $\begin{array}{l}10 \\
0\end{array}$ & $\begin{array}{l}10 \\
0\end{array}$ & 0.37 & 32.6 & -7.9 \\
\hline 5 & 75 & 25 & \begin{tabular}{|l}
10 \\
0 \\
\end{tabular} & $\begin{array}{l}10 \\
0 \\
\end{array}$ & 0.50 & 29.5 & -16.7 \\
\hline
\end{tabular}


Table 11. Test results of cubes using PCE plasticizer

\begin{tabular}{|l|l|l|l|l|l|l|c|}
\hline \multirow{2}{*}{$\begin{array}{c}\text { Sampl } \\
\text { e }\end{array}$} & \multicolumn{6}{|c|}{ Percentage (\%) } & \multicolumn{2}{c|}{\begin{tabular}{c} 
Fiber \\
Concret \\
\cline { 2 - 6 }
\end{tabular}} & $\begin{array}{l}\text { Ceme } \\
\text { nt }\end{array}$ & $\begin{array}{l}\text { Fl } \\
\text { y } \\
\text { as } \\
\text { h }\end{array}$ & $\begin{array}{l}\text { FA } \\
\text { A }\end{array}$ & $\begin{array}{l}\text { PV } \\
\text { A } \\
\text { Fibe } \\
\text { r }\end{array}$ & $\begin{array}{c}\text { e } \\
\text { Chang } \\
\text { e }\end{array}$ & \\
\hline 1 & 75 & 25 & $\begin{array}{l}10 \\
0\end{array}$ & $\begin{array}{l}10 \\
0\end{array}$ & 0 & 35.4 & - \\
\hline 2 & 75 & 25 & $\begin{array}{l}10 \\
0\end{array}$ & $\begin{array}{l}10 \\
0\end{array}$ & 0.12 & 36.2 & +2.25 \\
\hline 3 & 75 & 25 & $\begin{array}{l}10 \\
0\end{array}$ & $\begin{array}{l}10 \\
0\end{array}$ & 0.25 & 41.2 & +16.38 \\
\hline 4 & 75 & 25 & $\begin{array}{l}10 \\
0\end{array}$ & $\begin{array}{l}10 \\
0\end{array}$ & 0.37 & 43.4 & +22.6 \\
\hline 5 & 75 & 25 & $\begin{array}{l}10 \\
0\end{array}$ & $\begin{array}{l}10 \\
0\end{array}$ & 0.50 & 42.6 & +16.9 \\
\hline
\end{tabular}

\subsubsection{Comparative Study Of plasticizer}

The Graph represents the comparison of strength variation between two plasticizer

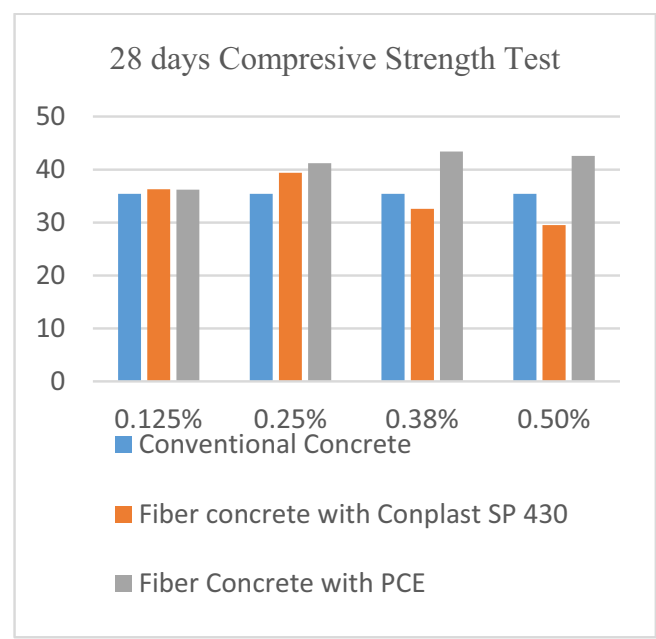

Fig. 6. Comparative study of 28 days

\subsection{Results of Split Tensile Strength}

\subsubsection{Test results for 7 days.}

The cylinders are tested after 7days of curing and are tabulated below in Table 10 and Table 11.

Table 12. Test results of Cylinder using Conplast SP-430

\begin{tabular}{|c|c|c|c|c|c|c|c|}
\hline \multirow{2}{*}{$\begin{array}{c}\text { Sam } \\
\text { ple }\end{array}$} & \multicolumn{5}{|c|}{ Percentage (\%) } & \multirow{2}{*}{$\begin{array}{c}\text { Fiber } \\
\text { Concr } \\
\text { ete }\end{array}$} & \multirow{2}{*}{$\begin{array}{c}\text { \% } \\
\text { Cha } \\
\text { nge }\end{array}$} \\
\hline & $\begin{array}{l}\text { Ceme } \\
\text { nt }\end{array}$ & $\begin{array}{l}\text { Fl } \\
y \\
\text { as } \\
\text { h }\end{array}$ & FA & $\mathrm{CA}$ & $\begin{array}{l}\text { PV } \\
\text { A } \\
\text { Fibe } \\
r\end{array}$ & & \\
\hline 1 & 75 & 25 & 100 & 100 & 0 & 1.13 & - \\
\hline 2 & 75 & 25 & 100 & 100 & 0.12 & 1.25 & $\begin{array}{l}+10.6 \\
2 \\
\end{array}$ \\
\hline 3 & 75 & 25 & 100 & 100 & 0.25 & 1.46 & +29.2 \\
\hline 4 & 75 & 25 & 100 & 100 & 0.37 & 1.37 & $\begin{array}{l}+21.2 \\
4\end{array}$ \\
\hline 5 & 75 & 25 & 100 & 100 & 0.50 & 1.09 & -3.54 \\
\hline
\end{tabular}

Table 13. Test results of the cylinder using PCE

\begin{tabular}{|c|c|c|c|c|c|c|c|}
\hline \multirow{2}{*}{$\begin{array}{c}\text { Sam } \\
\text { ple }\end{array}$} & \multicolumn{5}{|c|}{ Percentage (\%) } & \multirow{2}{*}{$\begin{array}{c}\text { Fiber } \\
\text { Concr } \\
\text { ete }\end{array}$} & \multirow{2}{*}{$\begin{array}{c}\% \% \\
\text { Cha } \\
\text { nge }\end{array}$} \\
\hline & $\begin{array}{l}\text { Ceme } \\
\text { nt }\end{array}$ & $\begin{array}{l}\text { Fl } \\
\mathrm{y} \\
\text { as } \\
\mathrm{h}\end{array}$ & FA & $\mathrm{CA}$ & $\begin{array}{l}\text { PV } \\
\text { A } \\
\text { Fibe } \\
\mathrm{r}\end{array}$ & & \\
\hline 1 & 75 & 25 & 100 & 100 & 0 & 1.13 & - \\
\hline 2 & 75 & 25 & 100 & 100 & 0.12 & 1.27 & +12.4 \\
\hline 3 & 75 & 25 & 100 & 100 & 0.25 & 1.27 & +12.4 \\
\hline 4 & 75 & 25 & 100 & 100 & 0.37 & 1.4 & +23.9 \\
\hline 5 & 75 & 25 & 100 & 100 & 0.50 & 1.34 & $\begin{array}{l}+18.5 \\
8\end{array}$ \\
\hline
\end{tabular}

\subsubsection{Comparative Study Of plasticizer}

The Graph represents the comparison of strength variation between two plasticizer

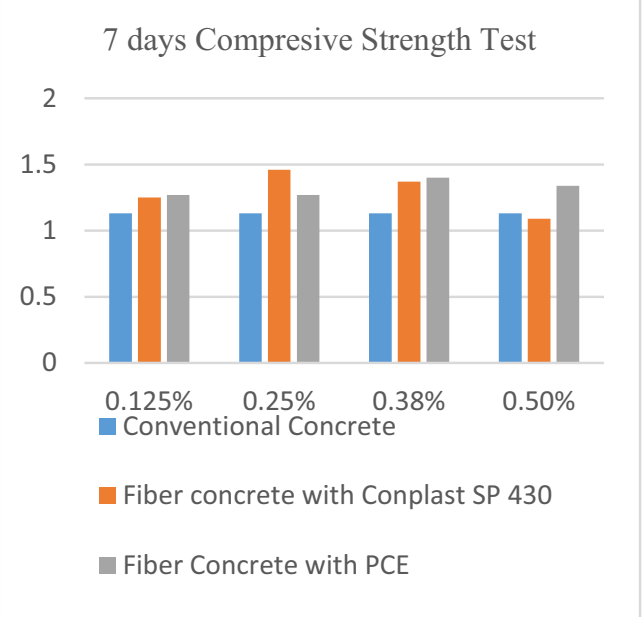

Fig. 7. Comparative study of 7 days.

\subsubsection{Split Tensile Strength Test results for 28 days.}

The cylinders are tested after 7days of curing and are tabulated below in Table 10 and Table 11.

Table 14. Test results of Cylinder using Conplast $\quad$ SP-430 plasticizer.

\begin{tabular}{|c|c|c|c|c|c|c|c|}
\hline \multirow{2}{*}{$\begin{array}{l}\text { Sampl } \\
\text { e }\end{array}$} & \multicolumn{5}{|c|}{ Percentage (\%) } & \multirow{2}{*}{$\begin{array}{l}\text { Fiber } \\
\text { Concret } \\
\text { e }\end{array}$} & \multirow{2}{*}{$\begin{array}{l}\text { o/ } \\
\text { Chang } \\
\text { e }\end{array}$} \\
\hline & $\begin{array}{l}\text { Ceme } \\
\text { nt }\end{array}$ & $\begin{array}{l}\mathrm{Fl} \\
\mathrm{y} \\
\text { as } \\
\mathrm{h}\end{array}$ & FA & $\begin{array}{l}\mathrm{C} \\
\mathrm{A}\end{array}$ & $\begin{array}{l}\text { PV } \\
\text { A } \\
\text { Fibe } \\
\text { r }\end{array}$ & & \\
\hline 1 & 75 & 25 & $\begin{array}{l}10 \\
0\end{array}$ & $\begin{array}{l}10 \\
0\end{array}$ & 0 & 2.83 & - \\
\hline 2 & 75 & 25 & $\begin{array}{l}10 \\
0\end{array}$ & $\begin{array}{l}10 \\
0\end{array}$ & 0.12 & 3.12 & +10.24 \\
\hline 3 & 75 & 25 & $\begin{array}{l}10 \\
0 \\
\end{array}$ & $\begin{array}{l}10 \\
0\end{array}$ & 0.25 & 3.64 & +28.42 \\
\hline 4 & 75 & 25 & $\begin{array}{l}10 \\
0 \\
\end{array}$ & $\begin{array}{l}10 \\
0\end{array}$ & 0.37 & 3.43 & +21.20 \\
\hline 5 & 75 & 25 & $\begin{array}{l}10 \\
0\end{array}$ & $\begin{array}{l}10 \\
0\end{array}$ & 0.50 & 2.72 & -3.89 \\
\hline
\end{tabular}


Table 15. Test results of the cylinder using polycarboxylic ether-based plasticizer

\begin{tabular}{|l|l|l|l|l|l|l|c|}
\hline \multirow{2}{*}{$\begin{array}{c}\text { Sampl } \\
\text { e }\end{array}$} & \multicolumn{6}{|c|}{ Percentage (\%) } & \multicolumn{2}{c|}{$\begin{array}{c}\text { Fiber } \\
\text { Concret } \\
\text { nt }\end{array}$} & $\begin{array}{l}\text { Ceme } \\
\text { y } \\
\text { as } \\
\text { h }\end{array}$ & $\begin{array}{l}\text { FA } \\
\text { A }\end{array}$ & $\begin{array}{l}\text { A } \\
\text { A }\end{array}$ & $\begin{array}{c}\text { Fibe } \\
\text { Chang } \\
\text { e }\end{array}$ \\
\hline 1 & 75 & 25 & $\begin{array}{l}10 \\
0\end{array}$ & $\begin{array}{l}10 \\
0\end{array}$ & 0 & 2.83 & - \\
\hline 2 & 75 & 25 & $\begin{array}{l}10 \\
0\end{array}$ & $\begin{array}{l}10 \\
0\end{array}$ & 0.12 & 3.18 & +12.37 \\
\hline 3 & 75 & 25 & $\begin{array}{l}10 \\
0\end{array}$ & $\begin{array}{l}10 \\
0\end{array}$ & 0.25 & 3.4 & +20.14 \\
\hline 4 & 75 & 25 & $\begin{array}{l}10 \\
0\end{array}$ & $\begin{array}{l}10 \\
0\end{array}$ & 0.37 & 3.5 & +23.67 \\
\hline 5 & 75 & 25 & $\begin{array}{l}10 \\
0\end{array}$ & $\begin{array}{l}10 \\
0\end{array}$ & 0.50 & 3.34 & +18.02 \\
\hline
\end{tabular}

\subsubsection{Comparative Study Of plasticizer}

The Graph represents the comparison of strength variation between two plasticizers.

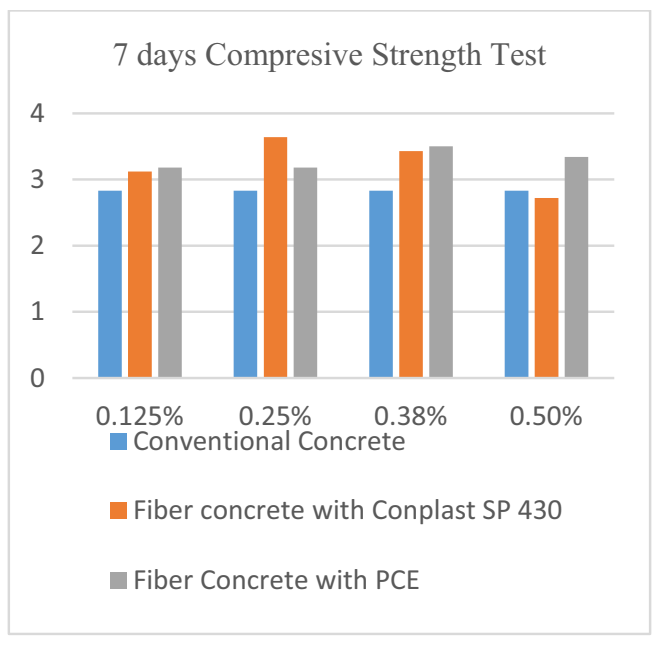

Fig. 8. Comparative study of 28 days.

\section{Conclusion}

1. Optimum dosage of PVA fibers achieved at $0.25 \%$ volume fraction for all mixes.

2. Workability and Strength-Effectiveness of Conplast SP430 based mixes are more compared to PCE-based mixes.

3. Improvement of compressive strength is not significant with the addition of PVA fibers whereas strength improvement in Split Tensile strength is more.

4. Strength effectiveness of concrete in Compressive strength with the addition of PVA fibers is $11.3 \%$ and $16.38 \%$ for M30 grade Concrete using CN SP430 and PCE.

5. Strength effectiveness of concrete in Split Tensile strength with the addition of PVA fibers is $28.42 \%$ and $20.14 \%$ for M30 grade Concrete using CN SP430 and PCE.

\section{Reference}

1. Sukru Ozkan and Fuat Demir. Cons. and Bui. Mat.2020

2. Mohamed Said, T.S. Mustafa, Ali S. Shanour, and Mostafa M. Khalil. Cons. and Bui. Mat.-2020

3. Cong Ding, Liping Guo and Bo Chen. Cons. and Bui. Mat.-2020

4. Jia-Xiang Lin, Ying Song, Zhi-Hong Xie, YongChang Guo, Bing Yuan, Jun-Jie Zeng and Xiao Wei. J. of Bui. Engg.-2019.

5. T. Xie1, M. S. Mohamed Ali, P. Visintin, D. J. Oehlers and A. H. Sheikh. J. Compos. Constr-2018

6. Ming Cao, Chuanyong Wang, Ru Xia, Peng Chen, Jibin Miao, Bin Yang, Jiasheng Qian and Yongzhi Tang. Cons. and Bui. Mat.-2018

7. Wasim Abbass and M. Iqbal Khan. MATEC Web of Conferences-2018.

8. T.Srinivas and M. Abinay Raj, Int. J. of Eng.and Adv. Tech. (IJEAT), ISSN: 2249 - 8958, Volume-8 Issue6 (2019)

9. T.srinivas and P. Manoj Anand, Int. J. of Innov. Tech. and Explor. Eng.g (IJTTEE), ISSN: 2278-3075, Volume-8 Issue-12 (2019)

10. T.Srinivas and G. Sukesh Reddy, Int. J. of Eng.and Adv. Tech. (IJEAT), ISSN: 2249 - 8958, Volume-9 Issue-1 (2019)

11. T.Srinivas and R. N. Koushik, Int. J. of Innov. Tech. and Explor. Eng.g (IJITEE), ISSN: 2278-3075, Volume-8 Issue-12 (2019), PP 112-117.

12. K. Sai Gopi, Dr. T. Srinivas and S. P. Raju V, E3S Web of Conferences ICMED 184, 01084GRIET, 2829 February, https://doi.org/10.1051/e3sconf/2020184011084(20 20)

13. Jagannadha Kumar, M.V., Jagannadha Rao, K., Dean Kumar, B., Srinivasa Reddy, V., Int. J. of Civil Eng. and Tech., 9(7), pp. 1133-1141 (2018)

14. Ganta, J.K., Seshagiri Rao, M.V., Mousavi, S.S., Srinivasa Reddy, V., Bhojaraju, C., Structures 28, pp. 956-972 (2020)

15. Naidu, K.S.S.T., Rao, M.V.S., Reddy, V.S., Int. J. of Innov. Tech. and Explor. Eng.g (IJITEE), 8(9 Special Issue 2), pp. 641-642 (2019)

16. Chandana Priya, C., Seshagiri Rao, M.V., Srinivasa Reddy, V., Int. J. of Civil Eng. and Tech., 9(11), pp. 2218-2225 (2018)

17. Satya Sai Trimurty Naidu, K., Seshagiri Rao, M.V., Srinivasa Reddy, V., Int. J. of Civil Eng. and Tech., 9(11), pp. 2383-2393 (2018)

18. Supriya, Y., Srinivasa Reddy, V., Seshagiri Rao, M.V., Shrihari, S., Int. J. of Rec. Tech. and Engi., 
8(3), pp. 5381-5385 (2019)

19. Kotkunde, N., Krishna, G., Shenoy, S.K., Gupta, A.K., Singh, S.K. International Journal of Material Forming, 10 (2), pp. 255-266 (2017)

20. Govardhan, D., Kumar, A.C.S., Murti, K.G.K., Madhusudhan Reddy, G. Materials and Design, 36, pp. 206-214. (2012)

21. Kumar, P., Singhal, A., Mehta, S., Mittal, A. Journal of Real-Time Image Processing, 11 (1), pp. 93-109. (2016)

22. Raghunadha Reddy, T., Vishnu Vardhan, B., Vijayapal Reddy, P. International Journal of Applied Engineering Research, 11 (5), pp. 3092-3102 (2016)

23. Hussaini, S.M., Krishna, G., Gupta, A.K., Singh, S.K. Journal of Manufacturing Processes, 18, pp. 151-158 (2015)

24. Ting Huang and Y.X. Zhang. Sus. Sol. in Struct.Engg. and Cons.-2014

25. Shin-ichi Torigoe1, Tetsuo Horikoshi1, Atsuhisa Ogawa, Tadashi Saito and Toshihiro Hamada J. of Ad. Con. Tech.-2003.

26. Victor C. Li, Cynthia Wu, Shuxin Wang, Atsuhisa Ogawa and Tadashi Saito. ACI Mat. J.-2002 